\title{
Effect of Temperature-Time Couple on the Quality of Isongo, A Burundian Traditional Banana Wine
}

\author{
NZIGAMASABO Aloys* MUVUNYI Robert HABIYAMBERE Dieudonné \\ University of Burundi, Faculty of agronomy and bio-engineering, CRSTA laboratory, \\ Avenue de 1'UNESCO, n 2, BP 2940 Bujumbura, Burundi. \\ *Email of corresponding author: naloys@gmail.com
}

\begin{abstract}
The banana wine submitted to different pasteurization temperatures was kept for two weeks at room temperature and the quality parameters were analyzed prior to pasteurization, after one week and after two weeks. The observations were made on the physico-chemical, microbiological parameters and organoleptic qualities. The results of the analyses carried out lead us to conclude that the banana wine produced by craftsmen and consumed in Burundi is poorly prepared but that it could acquire many physico-chemical, microbiological and organoleptic qualities if their manufacture were well conducted. Among the temperature and time couples studied, pasteurization at $64^{\circ} \mathrm{C}$ for 8 minutes gives good qualitative results after two weeks of storage. It is for this reason that the treatment of the banana wine by heat $\left(64^{\circ} \mathrm{C}\right.$ during 8 minutes) after fermentation is recommended to correct deficiencies that appear during the conservation of this product.

Keywords: Banana wine, temperature-time couple, physico- chemical, microbiological parameters, organoleptic
\end{abstract} qualities

DOI: $10.7176 / \mathrm{FSQM} / 113-04$

Publication date: February $28^{\text {th }} 2022$

\section{Introduction}

Banana is a crop adapted to low altitude of tropical regions (Central America, Caribbean, West Africa, Indonesia, Australia) where it is mostly grown for export. The high altitude banana varieties, found in the highlands of East Africa, constitute a specific group that is relatively less well known ( Bigirimana et Njejimana, 1999, Mujaayezu, 1990, Semajeje,1986).

In Burundi, the banana is cultivated in all natural regions except for the highlands of Mugamba and Bututsi where the altitude exceeds $2000 \mathrm{~m}$. There are four types of banana varieties in Burundi: cooking bananas, wine bananas, dessert bananas and plantains (, Kanyaruguru, 1999 ,Bagankunda, 1987).

The wine varieties are by far the most frequent, followed by the cooking varieties, the dessert varieties and the plantains. The first are used to manufacture beer and wine. Its production is simple and is known all over the country and it is one of the products accessible to the low income population, because of its selling price and the production techniques used (Nzigamasabo et Nimpagaritse, 2009).

Nevertheless, the poor conditions of manufacture and storage of banana wine, present various risks of contamination likely to affect the health of consumers. It is therefore strongly recommended to manufacture banana wine in a hygienic way in order to ensure the health of the consumers.

Isongo, a Burundian, Traditional banana wine is a beverage obtained by fermenting banana juice using sorghum flour as yeast source. It is made by hand and uses traditional tools which constitute a favorable ground for the proliferation of microorganisms. Since hygiene and sanitation are not respected and preservation treatments are not applied, this result in wine of questionable quality which can have implications on the health of consumers (Irambona, 2008). In Burundi, there are no studies made on the methods of preservation of the quality of banana wine by heat that is why in the framework of our work, we were interested in the treatment of banana wine by heat which is one of the techniques of preservation of the quality of food products.

This study aims to compare the effects of different pasteurization temperatures on the physico-chemical, microbiological and organoleptic qualities of wine during different storage times. Thus, the banana wine was subjected to different temperature-time

couples calculated using the following formula: $\mathrm{t}=\mathrm{t} * .10^{-\frac{\mathrm{T}-\mathrm{T} *}{\mathrm{Z}}}$

Where: $\mathrm{t}=$ processing time, $\mathrm{t}^{*}=$ reference treatment time, $\mathrm{T}^{*}=$ reference temperature $\left(60^{\circ} \mathrm{C}\right), \mathrm{T}=$ temperature to which the product will be subjected and is chosen arbitrarily, $\mathrm{z}=\mathrm{It}$ is a thermo resistance factor.

\section{Material and Methods}

\subsection{Banana collection and processing}

Wine banana varieties were purchased on the local market and transported to the laboratory for processing and analysis. The traditional processing techniques as described by Nzigamasabo et Nimpagaritse (2009) were used. Briefly, green bananas were ripened for 3-5 days in a covered warm place with bananas leaves to insure uniform 
temperature. The ripe bananas were mixed with spear grass. Juice was then extracted by squeezing the mixture with their hand. The process of squeezing was continued until all the pulp is exhausted of juice. The juice was filtered through grass held in a bottle.

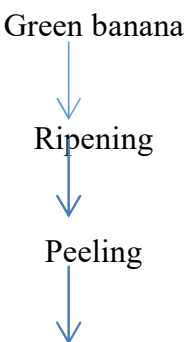

Mixed with spear grass and mashing with hands

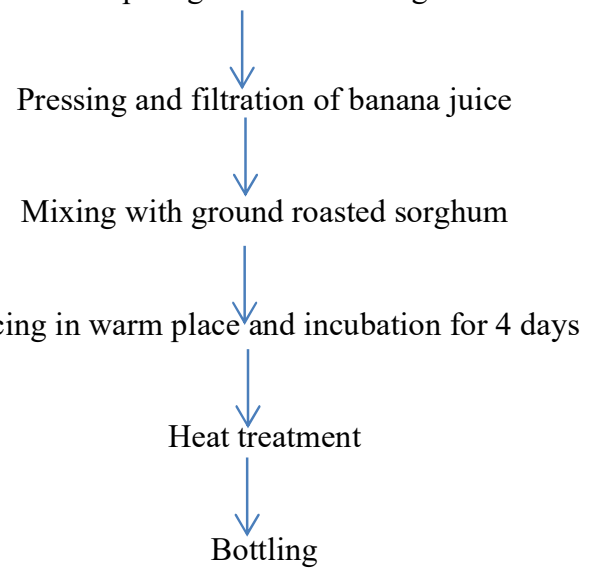

Figure 1. Flow chart of banana wine manufacture

\subsection{Determination of physicochemical Characteristics}

After the fermentation the $\mathrm{pH}$, titratable acidity, fixed acidity and alcoholic degree were determined using official methods of analysis of AOAC (2012).

\subsection{Microbiological analysis}

2.3.1. Material sterilization

All materials used for microbial contents analysis were washed with water, dried and sterilized in autoclave at $121^{\circ} \mathrm{C}$ for 15 minutes apart for Petri dishes and pipettes which were sterilized using ethanol 70\%. All techniques were done aseptically around the Bunsen burner. All of working tables were cleaned and disinfected with ethanol $70 \%$ so as to prevent cross contamination that could occur during operations.

2.3.2. Culture medium preparation

PCA was used for the determination of the total Aerobic Mesophilic Flora. 23,5 g was suspended in $100 \mathrm{ml}$ of water, heated until completely dissolved and autoclaved at $121^{\circ} \mathrm{C}$ for 15 minutes, cooled to $45-50^{\circ} \mathrm{C}$ and poured carefully into Petri dishes (Bunani et al, 2020, Kavishe et Matemu, 2015).

Mac Conkey agar was used for isolation and differentiation of total and fecal coliforms, staphyloccus , salmonella and shigella. $50 \mathrm{~g}$ was suspended in $1000 \mathrm{ml}$ of water, heated until completely dissolved and autoclaved at $121^{\circ} \mathrm{C}$ for 15 minutes, cooled to $45-50{ }^{\circ} \mathrm{C}$ and poured carefully into Petri dishes ( Bunani et al, 2020, Kavishe et Matemu, 2015).

CSA (clostridium Selective Agar ) used for the isolation of clostridia, 44g was suspended in $1000 \mathrm{ml}$ of water, heated until completely dissolved and autoclaved at $121^{\circ} \mathrm{C}$ for 15 minutes, cooled to $45-50^{\circ} \mathrm{C}$ and poured carefully into Petri dishes ( Bunani et al, 2020, Kavishe et Matemu, 2015).

PDA was used for isolation and differentiation of mold and yeast. $39 \mathrm{~g}$ was suspended in $1000 \mathrm{ml}$ of water, heated until completely dissolved and autoclaved at $121^{\circ} \mathrm{C}$ for 15 minutes, cooled to $45-50^{\circ} \mathrm{C}$ and poured carefully into Petri dishes. Chloramphenicol was used to suppress the growth of bacteria ( Bunani et al, 2020, Kavishe et Matemu, 2015).

2.3.3. Serial dilution

Dilutions were very important in order to get a number of colonies that could be countable. Seven test tubes were 
filled with $1 \mathrm{ml}$ of sterilized traditional banana wine as shown below on Fig. 1. By using a micropipette, $1 \mathrm{ml}$ of the original sample was taken and put in $9 \mathrm{ml}$ of peptone water (dilution $10^{-1}$ ). After mixing, $1 \mathrm{ml}$ was taken from that tube and then put in the next tube (dilution $10^{-2}$ ). The same process was repeated up to the tube number seven.

2.3.4. Inoculation

The inoculation has been done by putting $1000 \mu \mathrm{l}$ of the diluted suspension samples into Petri dishes by using micropipette. Then the samples were spreaded on the agar media by using a spreader.

2.3.5.Incubation

The Petri dishes were put into incubator for 24 hours at $37^{\circ} \mathrm{C}$ to enable Aerobic Mesophilic Flora to grow on PCA, clostridia on CSA, fecal coliform, E.coli, staphylococcus, salmonella, and shigella on MCA. For Petri dishes of PDA, they were putted for 72 hours at $25-30^{\circ} \mathrm{C}$ to enable yeasts and mold to grow ( Bunani et al, 2020, Kavishe et Matemu, 2015).

2.3.6.Description Of Colonies

In order to differentiate the microorganisms, the description of colonies is needed. For our study, the colonies were differentiated using the following characteristics:

Size: diameter in millimeter, Form: Punctiform, circular, filamentous, irregular, rhizoid, Elevation: flat,raised convex, pulvinate, umbonate, umbilicate, Margin: entire, undulate, lobate, Color: white, yellow, black, buff,orange, pink, Density: opaque, translucent, transparent,

Consistency: viscid, membranous, brittle, butyrins.

2.3.7.Enumeration

The enumeration of the microbial load was performed on the surface, after the appropriate incubation period for each microorganism. This was done using an electric colony counter with a magnifying glass and separating the colonies on the petri dishes with a pen marker.

\subsection{Sensory Analysis}

Sensory evaluation was carried out to know the acceptability of the wine by carrying out In- house consumer acceptability test using in-house panelists, according to the method described by Nwobodo (2013). Sensory evaluation was carried out by 10 untrained panelists who were selected based on their availability, objectivity and being conversant with wine tasting. The sensory attributes evaluated were color, taste/ mouth feel, smell and clarity on a 5-point hedonic scale (where 1 represents dislike very much and 5 represents like very much). The wine samples were served in clean plastic cups to individual panelist in a booth in a well-lit Environment Where There Was No Interference For Bias Expression.

\subsection{Statistical analysis}

The experiments were conducted in triplicate and the results were expressed as mean with standard deviation. Statistical analysis of the data was performed using SPSS Package Program. Statistical significance was taken at $95 \%$ confidence interval when $\mathrm{p}<0.05$. When Analysis of Variance (ANOVA) revealed a significant effect $(\mathrm{p}<0.05)$, the data means were compared by the least significant difference (Duncan's Multiple Range test) test.

\section{Results and discussion}

\subsection{Physico chemical parameters}

The physico-chemical analysis of banana wine treated at different temperature-time couples (or pasteurization) was focused on $\mathrm{pH}$, alcoholic degree, volatile acidity, fixed acidity and total acidity. The results are presented in Table 1.

The $\mathrm{pH}$ of the wine was determined since it has a great influence on the properties of the wine, as well as on its biological and chemical stability. Acidity confers to the wine a better microbiological and physico-chemical stability by limiting the development of micro-organisms and by increasing the antiseptic fraction of the sulphur dioxide, it is also a pillar of the gustatory balance.

The results show a decrease in $\mathrm{pH}$ compared to the $\mathrm{pH}$ before heat treatment $(\mathrm{pH}=3.82 \pm 0,028)$. It is $3,78 \pm 0,012$ and $3,76 \pm 0,041$ for the wine treated at $60^{\circ} \mathrm{C}$ for $30 \mathrm{~min}$ respectively after 7 days and 14 days, that treated at $62^{\circ} \mathrm{C}$ for $16 \mathrm{~min}$ has a $\mathrm{pH}$ of $3,77 \pm 0,025$ and $3,74 \pm 0,043$ respectively after 7 and 14 days.

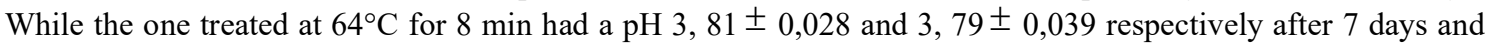
14 days. The results also show that the $\mathrm{pH}$ of the banana wine treated at $62^{\circ} \mathrm{C}$ for 16 min has a lower $\mathrm{pH}$ than the other treatments, but there is was not a significance difference between different wines $(\mathrm{p}<0,05)$.

We also noted that the $\mathrm{pH}$ decreased during the storage time. The same trend was observed by Gavimash et al (2012). The pH of banana wine pasteurized at different temperature-time couples remain within the recommended norms of wines, i.e. $\mathrm{pH}$ varying between 3 and 5.

The result of the $\mathrm{pH}$ values in the experiment shows progressive decrease in $\mathrm{pH}$ value with storage time. 
These results showed that the wine became lightly acidic as the storage time progressed. The drop in $\mathrm{pH}$ records the utilization of the sugar present in the must by the yeast. The finding from this study suggests that yeasts could strive under acidic pH (Akubor et. al., 2003) and that these yeasts were not completely inactivated during the pasteurization process.

Table 1: Physico-chemical parameters of banana wine treated at different time-temperature couples

\begin{tabular}{|c|c|c|c|c|c|c|c|}
\hline & \multicolumn{7}{|c|}{ Temperature-time Couple } \\
\hline & \multirow{2}{*}{$\begin{array}{l}\text { Before } \\
\text { pasteurization }\end{array}$} & \multicolumn{3}{|c|}{ Before pasteurization } & \multicolumn{3}{|c|}{14 days after pasteurization } \\
\hline & & $\begin{array}{l}60^{\circ} \text { Cduring } 30 \\
\min \end{array}$ & $\begin{array}{l}62^{\circ} \text { Cduring } 16 \\
\min \end{array}$ & $\begin{array}{l}64^{\circ} \mathrm{Cduring} \quad 8 \\
\min \end{array}$ & $\begin{array}{l}60^{\circ} \text { Cduring } 30 \\
\min \end{array}$ & $\begin{array}{l}62^{\circ} \text { Cduring } 16 \\
\min \end{array}$ & $\begin{array}{l}64^{\circ} \text { Cduring } 8 \\
\min \end{array}$ \\
\hline pH & $3,82^{\mathrm{a}} \pm 0,028$ & $3,78^{\mathrm{a}} \pm 0,012$ & $3,77^{a} \pm 0,025$ & $3,81^{\mathrm{a}} \pm 0,028$ & $, 76^{\mathrm{a}} \pm 0,041$ & $3,74^{a} \pm 0,043$ & $3,79^{a} \pm 0,039$ \\
\hline $\begin{array}{l}\text { Alcohol } \\
\text { content } \\
(\%) \\
\end{array}$ & $3,85^{a} \pm 0,12$ & $3,89^{a} \pm 0,233$ & $4,44^{c} \pm 0,225$ & $4,03^{b} \pm 0,205$ & $3,97^{b} \pm 0,153$ & $4,47^{c} \pm 0,231$ & $4,05^{b} \pm 0,227$ \\
\hline $\begin{array}{l}\text { Titratable } \\
\text { acidity }(\mathrm{g} / \mathrm{l})\end{array}$ & $4,6^{a} \pm 0,137$ & $4,6^{a} \pm 0,137$ & $5,2^{c} \pm 0,615$ & $4,9^{b} \pm 0,041$ & $5,3^{\mathrm{c}} \pm 0,085$ & $5,0^{b} \pm 0,143$ & $4,7^{a} \pm 0,707$ \\
\hline $\begin{array}{l}\text { Fixed } \\
\text { acidity (g/l) }\end{array}$ & $2,9^{\mathrm{a}} \pm 0,095$ & $3,2^{\mathrm{c}} \pm 0,745$ & $3,2^{\mathrm{c}} \pm 0,745$ & $2,7^{b} \pm 0,083$ & $2,9^{a} \pm 0,095$ & $2,8^{\mathrm{a}, \mathrm{b}} \pm 0,095$ & $2,9^{a} \pm 0,044$ \\
\hline $\begin{array}{l}\text { Volatile } \\
\text { acidity }(\mathrm{g} / \mathrm{l})\end{array}$ & $1,4^{a} \pm 0,096$ & $1,4^{\mathrm{a}} \pm 0,096$ & $2,0^{b} \pm 0,136$ & $2,2^{c} \pm 0,144$ & $2,6^{\mathrm{d}} \pm 0,065$ & $2,2^{\mathrm{c}} \pm 0,124$ & $1,9^{\mathrm{b}} \pm 0,141$ \\
\hline
\end{tabular}

Values followed by different letters within rows are significantly different $(\mathrm{P}<0.05)$. Mean $\pm \mathrm{SD}(\mathrm{n}=3)$.

The alcohol in a wine is the result of the transformation, total or partial, of the sugar contained in the must. The alcohol content influences the $\mathrm{pH}$, wine quality, conservation and market value. Its content depends on the initial sugar concentration of the must, the fermentation conditions that can slightly vary the yield of the conversion (Otgbayo, Akwa, Tanimola, 2020, Randrianantoandro and Andriamamisa, 2018)

Alcohol content increased with storage time for all pasteurization temperatures, it was the highest for the wine treated at $62^{\circ} \mathrm{C}$ for $16 \mathrm{~min}(4,47 \pm 0,231)$ and he lowest for the wine pasteurized at $64^{\circ} \mathrm{C}$ for $8 \mathrm{~min}$ $(4,05 \pm 0,227)$. Significant difference $(p>0,05)$ has been observed between these heat preserved wines.

The titratable acidity of wine is one of the essential constituents of its organoleptic as well as of its conservation. It is therefore important to follow it periodically throughout the winemaking process, especially during the alcoholic and malolactic fermentation but also until the bottling (Randrianantoandro et Andriamamisa, 2018). The total acidity is linked to all the acids present in the wine and translates the gustatory characteristics of the wine.

The banana wine treated at $60^{\circ} \mathrm{C}$ for $30 \mathrm{~min}$ had respectively a titratable acidity of $4,6 \pm 0,137 \mathrm{~g}$ tartaric acid/1 banana wine after 7 days and 5,3 $\pm 0,085 \mathrm{~g}$ tartaric acid/1 banana wine after 14 days. The wine treated at $62^{\circ} \mathrm{C}$ for $16 \mathrm{~min}$ has a titratable acidity of $5,2 \pm 0,615 \mathrm{~g}$ tartaric acid/1 banana wine and $5,0 \pm 0,143 \mathrm{~g}$ tartaric acid/1 banana wine after 7 and 14 days respectively. While the one treated at $64^{\circ} \mathrm{C}$ for 8 min has respectively $4,9 \pm 0,041 \mathrm{~g}$ of tartaric acid $/ 1$ of banana wine and 4,7 $\pm 0,707 \mathrm{~g}$ of tartaric acid after 7 and 14 days.

There is a gradual increase of titratable acidity as the storage time progressed. As the production of alcohol is due to the activity of yeasts and other bacteria, these results show that the different time-temperature couples did not totally inactivate the microorganisms and that they continue to degrade the substrates with the production of alcohol and acids. Despite the observed significance difference between the samples, we notice that the timetemperature couple of $64 \mathrm{C}-8 \mathrm{~min}$ is the best compared to the other time-temperature couples.

The volatile acidity is constituted by the part of the fatty acids belonging to the acetic series, which are found in the wines in the free state, and in the solified state. It is formed essentially by acetic acid, accompanied by small quantities of propionic and butyric acids. The volatile acidity is an important parameter of the quality of wines (Delanoë D. et al., 2007). It gives bouquet to the wine.

These acids are formed naturally in very small quantities during alcoholic and malolactic fermentations. They can also be formed accidentally as a result of bacterial development. But when the dose is too high, as in our case, the wine becomes cloudy and pitted. The determination of the volatile acidity of a wine also allows to know the sanitary state of the wines.

The wine treated at $60^{\circ} \mathrm{C}$ for $30 \mathrm{~min}$ has respectively $1,4 \pm 0,096 \mathrm{~g}$ and $2,6 \mathrm{~g}$ of sulfuric acid $/ 1$ after 7 days and 14 days, the one treated at $62^{\circ} \mathrm{C}$ for $16 \mathrm{~min}$ has $2,0 \pm 0,136 \mathrm{~g}$ and $2,2 \pm 0,124 \mathrm{~g}$ of sulfuric acid $/ 1$ while it is respectively $2,2 \pm 0,144 \mathrm{~g}$ and $1,9 \pm 0,141 \mathrm{~g}$ of sulfuric acid $/ 1$ for the treatment at $64^{\circ} \mathrm{C}$ for $8 \mathrm{~min}$.

Since it is wines with low volatile acidity that are recommended, it is the $64^{\circ} \mathrm{C} 8 \mathrm{~min}$ treatment that is likely to preserve the quality of the wine because the low volatile acidity does not cause the wine to deteriorate in contact with air.

\subsection{Microbiological Analysis Results}

The purpose of microbiological analysis of wines is to monitor the alcoholic and/or malolactic fermentations and to detect the risks of microbial alterations. This then allows the detection of any anomaly, not only in the finished 
product, but also during the different phases of its manufacture (OIV, 2015).

The results of microbiological analysis of pasteurized banana wine are given in Table 2 and concern the detection of total aerobic mesophilic flora, fecal coliforms including E. Coli, salmonella and shigella, clostridia, staphylococci, yeasts and molds.

Table 2: Microbiological parameters of banana wine treated at different time -temperature couples

\begin{tabular}{|c|c|c|c|c|c|c|c|}
\hline & & \multicolumn{6}{|c|}{ Temperature time couple } \\
\hline & \multirow{2}{*}{$\begin{array}{l}\text { Before } \\
\text { pasteurizati } \\
\text { on }\end{array}$} & \multicolumn{3}{|c|}{7 days after pasteurization } & \multicolumn{3}{|c|}{14 days after pasteurization } \\
\hline & & $\begin{array}{l}60^{\circ} \mathrm{C} \\
\text { during } 30 \\
\min \end{array}$ & $\begin{array}{l}62^{\circ} \mathrm{C} \\
\text { during } 16 \\
\min \end{array}$ & $\begin{array}{l}64^{\circ} \mathrm{C} \\
\text { during } 8 \\
\min \end{array}$ & $\begin{array}{l}60^{\circ} \mathrm{C} \\
\text { during } 30 \\
\min \end{array}$ & $\begin{array}{l}62^{\circ} \mathrm{C} \\
\text { during } 16 \\
\min \end{array}$ & $\begin{array}{l}64^{\circ} \mathrm{C} \\
\text { during } 8 \\
\min \end{array}$ \\
\hline $\begin{array}{l}\text { Total } \\
\text { aerobic } \\
\text { mesophilic } \\
\text { flora }\end{array}$ & $\begin{array}{l}6,089^{a} \pm 0 \\
043\end{array}$ & $\begin{array}{l}4,620^{\mathrm{b}} \pm 0 \\
006\end{array}$ & $\begin{array}{l}4,620^{\mathrm{b}} \pm 0 \\
006\end{array}$ & $\begin{array}{l}4,021^{\mathrm{c}} \pm 0 \\
096\end{array}$ & $\begin{array}{l}3,954^{\mathrm{c}} \pm 0 \\
016\end{array}$ & $\begin{array}{l}3,954^{\mathrm{c}} \pm 0 \\
016\end{array}$ & $\begin{array}{l}3,556^{\mathrm{d}} \pm 0 \\
066\end{array}$ \\
\hline Yeasts & $\begin{array}{l}4,954^{\mathrm{a}} \\
\pm 0,049\end{array}$ & $\begin{array}{l}4,484^{\mathrm{b}} \pm 0 \\
030\end{array}$ & $\begin{array}{l}4,024^{c} \pm 0 \\
045\end{array}$ & $\begin{array}{l}3,903^{c} \pm 0 \\
064\end{array}$ & $\begin{array}{l}3,968^{c} \pm 0 \\
012\end{array}$ & $\begin{array}{l}3,863^{\mathrm{c}} \\
\pm 0,010 \\
\end{array}$ & $\begin{array}{l}3,380^{\mathrm{d}} \pm 0 \\
040\end{array}$ \\
\hline Fungi & $\begin{array}{l}4,337^{\mathrm{a}} \\
\pm 0,024\end{array}$ & $\begin{array}{l}3,845^{\mathrm{b}} \pm 0 \\
041\end{array}$ & $\begin{array}{l}3,653^{c} \pm 0 \\
029\end{array}$ & $\begin{array}{l}3,342^{\mathrm{d}} \pm 0 \\
054\end{array}$ & $\begin{array}{l}3,230^{\mathrm{d}} \pm 0 \\
104\end{array}$ & $\begin{array}{l}3,041^{\mathrm{e}} \\
\pm 0,053\end{array}$ & $\begin{array}{l}2,954^{\mathrm{e}} \pm 0 \\
057\end{array}$ \\
\hline $\begin{array}{l}\text { Fecal } \\
\text { coliform : } \\
\text { E. coli }\end{array}$ & $0^{\mathrm{a}}$ & $0^{\mathrm{a}}$ & $0^{\mathrm{a}}$ & $0^{\mathrm{a}}$ & $0^{\mathrm{a}}$ & $0^{\mathrm{a}}$ & $0^{\mathrm{a}}$ \\
\hline $\begin{array}{l}\text { Salmonela } \\
\text { and } \\
\text { shigella }\end{array}$ & $\begin{array}{l}3,079^{\mathrm{a}} \pm 0 \\
029\end{array}$ & $0^{\mathrm{b}}$ & $0^{\mathrm{b}}$ & $0^{\mathrm{b}}$ & $0^{\mathrm{b}}$ & $0^{\mathrm{b}}$ & $0^{\mathrm{b}}$ \\
\hline $\begin{array}{l}\text { Staphylloc } \\
\text { cus }\end{array}$ & $\begin{array}{l}3,176^{\mathrm{a}} \\
\pm 0,090\end{array}$ & $0^{\mathrm{b}}$ & $0^{\mathrm{b}}$ & $0^{\mathrm{b}}$ & $0^{\mathrm{b}}$ & $0^{\mathrm{b}}$ & $0^{\mathrm{b}}$ \\
\hline Clostridia & $\begin{array}{l}2,103^{a} \pm 0 \\
014\end{array}$ & $0^{\mathrm{b}}$ & $0^{\mathrm{b}}$ & $0^{\mathrm{b}}$ & $0^{\mathrm{b}}$ & $0^{\mathrm{b}}$ & $0^{\mathrm{b}}$ \\
\hline
\end{tabular}

Values followed by different letters within rows are significantly different $(\mathrm{P}<0.05)$. Mean $\pm \mathrm{SD}(\mathrm{n}=3)$.

The microbiological analysis shows that before pasteurization the banana wine contains a high microbial load of total aerobic mesophilic flora (logUFC,6,089 $\pm 0,043)$, yeasts $(\log U F C, 4,954 \pm 0,049)$ and fungi $(\log U F C, 4,337 \pm 0,024)$. This is quite understandable insofar as these microorganisms come from the manufacturer, the material and the ingredients used as ferment in particular sorghum. As the conservation time progresses, there is a progressive decrease of these microorganisms and this for all the couples time temperature. After 14 days storage time, the total aerobic mesophilic flora were $3,954 \pm 0,016,3,954 \pm 0,016$ and 3,556 $\pm 0,066$ in wine treated respectively at $60^{\circ} \mathrm{C}$ for $30 \mathrm{~min}, 62^{\circ} \mathrm{C}$ for $16 \mathrm{~min}$ and $64^{\circ} \mathrm{C}$ for 8 min. The yeasts found were respectively $3,968 \pm 0,012,3,863 \pm 0,010$ and 3,380 $\pm 0,040$ while fungi stood at 3,230 $\pm 0,104$, $3,041 \pm 0,053$ and $2,954 \pm 0,057$.

After 14 days of conservation, the wines treated at $64 \mathrm{C}$ for 8 min contained fewer microorganisms than the other wines (table 2). As mentioned by Bunani et al (2020), Bourgeois,Mescle et Zuccay, (1996), the alcohol content and the low $\mathrm{pH}$ would be at the origin of the decrease of these microorganisms.

Salmonella, shigella, staphyloccocus and costridia known to be pathogenic bacteria were present before pasteurization but were subsequently inactivated by these thermal treatments; they were not detected neither at the 7th nor at the 14th day of storage.The microbiological analysis allows us to conclude that the final product is perfectly safe for human consumption since the values obtained for the different evaluation criteria are below the accepted standards.

\subsection{Sensory Analysis Results}

The sensory analysis shows that the panelists liked the color, taste and smell of the banana wine very much and no significant difference ( $p>0,05)$ was detected between the different heat treatments. The color is yellowish, with a pleasant taste not very sweet with an aftertaste of banana and a good smell less pungent. 
Table 3 : Organoleptic parameters after 7 and 14 days storage.

\begin{tabular}{|c|c|c|c|c|}
\hline \multirow{2}{*}{$\begin{array}{l}\text { Organoleptic } \\
\text { parameters }\end{array}$} & \multicolumn{4}{|c|}{ Samples } \\
\hline & $\begin{array}{l}\text { Before } \\
\text { pasteurization }\end{array}$ & $\begin{array}{l}\text { Wine pasteurized at } \\
60 \mathrm{C} \text { during } 30 \mathrm{~min}\end{array}$ & $\begin{array}{l}\text { Wine pasteurized at } \\
62 \mathrm{C} \text { during } 16 \mathrm{~min}\end{array}$ & $\begin{array}{l}\text { Wine pasteurized at } \\
64 \mathrm{C} \text { during } 8 \mathrm{~min}\end{array}$ \\
\hline Color and clarity & $\begin{array}{l}\text { Yellowish } \\
4,5^{\mathrm{a}} \pm 0,2\end{array}$ & $\begin{array}{l}\text { Yellowish } \\
4,4^{\mathrm{a}} \pm 0,1\end{array}$ & $\begin{array}{l}\text { Yellowish } \\
4,5^{\mathrm{a}} \pm 0,1\end{array}$ & $\begin{array}{l}\text { Yellowish } \\
4,4^{\mathrm{a}} \pm 0,2\end{array}$ \\
\hline Taste & $\begin{array}{l}\text { pleasant, slightly } \\
\text { sweet taste, an } \\
\text { aroma with an } \\
\text { aftertaste of banana } \\
4,6^{\mathrm{a}} \pm 0,1\end{array}$ & $\begin{array}{l}\text { pleasant, slightly } \\
\text { sweet taste, an } \\
\text { aroma with an } \\
\text { aftertaste of banana } \\
4,5^{\mathrm{a}} \pm 0,1\end{array}$ & $\begin{array}{l}\text { pleasant, slightly } \\
\text { sweet taste, an } \\
\text { aroma with an } \\
\text { aftertaste of banana } \\
4,6^{\mathrm{a}} \pm 0,2\end{array}$ & $\begin{array}{l}\text { pleasant, slightly } \\
\text { sweet taste, an } \\
\text { aroma with an } \\
\text { aftertaste of banana } \\
4,5^{\text {a }} \pm 0,1\end{array}$ \\
\hline Smell & $\begin{array}{l}\text { Pleasant odor and } \\
\text { less pungent } \\
4,5^{\mathrm{a}} \pm 0,2\end{array}$ & $\begin{array}{l}\text { Pleasant odor and } \\
\text { less pungent } \\
4,5^{\mathrm{a}} \pm 0,2\end{array}$ & $\begin{array}{l}\text { Pleasant odor and } \\
\text { less pungent } \\
4,4^{\mathrm{a}} \pm 0,1\end{array}$ & $\begin{array}{l}\text { Pleasant odor and } \\
\text { less pungent } \\
4,5^{\mathrm{a}} \pm 0,2\end{array}$ \\
\hline
\end{tabular}

Values followed by different letters within rows are significantly different $(\mathrm{P}<0.05)$. Mean $\pm \operatorname{SD}(\mathrm{n}=3)$.

$5=$ Strongly liked, $4=$ liked, $3=$ Moderately liked, $2=$ disliked, $1=$ Strongly disliked

Values $=$ Mean \pm SD $(n=3)$

The conservation beyond two weeks is accompanied by the alteration of the organoleptic qualities. Given that the wines are subjected to thermal treatments of pasteurization, the origin of these deteriorations would be the material of conservation.

\section{ACKNOWLEDGMENT}

I express our heartfelt thanks to the supervisor Prof NZIGAMSABO Aloys who devoted a large part of his time to the supervision of this research. His guidance, comments, and advices led to the successful completion of this research project.

\section{CONCLUSION}

In Burundi, the majority of people consume banana alcoholic beverages. The food processors are not well educated and many lack education in food processing, hygienic and food handling. This may lead to high contamination of the banana alcoholic beverages. The objective of this work was to make banana wine at different temperature-time couples, to study the quality of the produced wines and to select the best temperaturetime couple. The treatment of banana wine at different time-temperature pairings and the monitoring of their physico-chemical, microbiological and organoleptic qualities at different storage times reveals that the wines are of good quality. The results of microbiological and organoleptic analysis do not show any difference between the time-temperature combinations used. On the other hand, differences were observed in the physical and chemical parameters. Based on the results obtained, we can conclude that treating wine at $64 \mathrm{oC}$ for 8 min is the best temperature time couple that can be recommended for banana wine manufacturers.

\section{References}

1. Akubor, P.I., Obio, S.O., Nwadomere, K.A \& Obiomah, E. Production and evaluation of banana wine. Plant Foods. Human Nutrition, (2003); 58: 1-6.

2. AOAC (2012). Official method of Analysis. 19th Edition, Association of Officiating Analytical Chemists, Washington DC.

3. Bagankunda S. (1987) : Etude taxonomique des banane de la collection de l'IRAZ (56 cultures), Bujumbura, UB, FACAGRO, Mémoire, 80p

4. Bigirimana S. et Njejimana .R, (1999) : Etude de l'influence variétale sur la qualité des vins de banane, Gitega U.B. ISA, Mémoire, 86 p.

5. Bourgeois,C.M., Mescle,J.F et Zuccay, (1996). Microbiologie alimentaire, Tome1 : Aspect microbiologique de la sécurité et de la qualité alimentaire technique et documentation, Lavoisier, Paris, 672p.

6. Bunani, P., Karine,B.,Isabane,R.S \& Ishimwe,P. Microbiological Analysis of Traditional Banana Wine Prepared by Local Population with Feet and Hands in North and East (Case Study Ngoma and Musanze). International Journal of Pharma Medicine and Biological Sciences, (2020), 9 (3), 134-139.

7. Carreño S. et Aristizábal L. Utilisation de bananes plantain pour produire du vin, 2003, InfoMusa. 12 (1) 1 3

8. Ciza, F. (2004) : Effet de la triple pasteurisation sur la qualité microbiologique et organoleptique des confitures d'ananas, de fraise, et de papaye fabriqués artisanalement au Burundi, Bujumbura, UB Facultés des Sciences : département de biologie, $55 \mathrm{p}$.

9. Delanoë, D., Maillard,C. et Maisondieu,D. (2007). Le vin : De l'analyse à l'élaboration. ISBN 2-7430-0497- 
5, Tec \& Doc Lavoisier, Londres-Paris-New-York. 206 pp.

10. FAO, (1989) : Manuel sur le contrôle de la qualité des produits alimentaires. Analyse Microbiologique. Alimentaire et nutrition, FAO, Rome.

11. Gavimath.C.C., Kalsekar. D.P., Raorane. C.J., Kulkarn. S. M. ,Gavade. B. G., Ravishankar. B.E. \& Hooli,V.R. Comparative Analysis Of Wine From Different Fruits. International Journal of Advanced Biotechnology and Research, (2012), 3 (4), 810-813.

12. Hangimana ,H. (2004) : Contribution à l'étude de la qualité microbiologique du vin de banane vendu en Mairie de Bujumbura : cas des zones NYAKABIGA, BWIZA et CIBITOKE, Bujumbura, UB, FACAGRO, Mémoire, 65p.

13. Irambona ,D. (2008) : Contribution à l'amélioration de la qualité du vin de banane. U.B, IPA, (Département de Chimie), $74 \mathrm{p}$.

14. Kamariza,F. (2004) : Caractérisation morphologique et physiologique des souches de saccharomyces cerevisiae isolés du vin de banane "INSONGO »: cas de la fermentation du glucose et du saccharose Bujumbura, U.B Faculté des Sciences (Département de biologie, mémoire, 46p.

15. Kanyaruguru ,J.P. (1999) : Contribution à l'étude de l'influence de certains facteurs climatiques sur quelques caractéristiques des jus et des vins de banane des variétés igitsiri (AAA-EA) et Kayinja (ABB) Gitega UB, ISA, Mémoire 64p.

16. Kavishe,S.K. et Matemu, A. Microbial Quality of Traditional Banana Alcoholic Beverages in Arusha, Tanzania, Food Science and Quality Management, (2015), vol 38, 28-29.

17. Kayath,A.C, Caractérisation physico-chimique et microbiologique du vin de banane (Mbamvu) produit en laboratoire selon un processus traditionnel, Mémoire, Marien Nguabi University, 55p

18. Larpent,J.P. et Bourgeois,C.M., (1996) : Microbiologie alimentaire aliments fermentés et fermentation alimentaire, $2^{\text {ème }}$ édition paris, Londres, New York, Lavoisier Tec et Doc 523p.

19. Larpent, J.P. (1997), Microbiologie alimentaire Technique de laboratoire, Paris, 1073p.

20. Manirakiza, P. (1991) : contribution à l'étude physico-chimiques des boissons alcoolisés à base de banane produits au Burundi : Bujumbura, UB, Faculté des Sciences (département de chimie) mémoire, 79p.

21. Mujawayezu, (1990). Classification numérique des bananes de l'Afrique et l'Est : collection de l'IRAZ, 61p.

22. Munyanganiza, B. (1975) : la technologie d'extraction du jus de banane et sa vinification : thèse de doctorat en sciences Agronomiques : Faculté des sciences Agronomiques de l'Etat de Gembloux, Belgique, $211 \mathrm{p}$.

23. Munyanganizi, B. et Coopeni, R. (1976) : Etude comparative de deux procédés et extraction au jus de banane appliqués aux deux variétés différents industries alimentaires agricole, $211 \mathrm{p}$.

24. Ndayikeza, R.. (2006) : Etude de la qualité microbiologique du vin d'ananas et liqueur bourasine fabriqué artisanalement au Burundi, UB, IPA (Département de Biologie, 36p.

25. Ndihokubwayo, D. (1991), Contribution à la valorisation de substrats sucrés par production d'éthanol : cas de mélasse, Bujumbura, U.B., FACAGRO, Mémoire, 64p.

26. Ndikuriyo, F. (2007): contribution à l'étude de la production des vins très alcooliques à partir des betteraves par chaptalisation UB, IPA, mémoire, 77p.

27. Nduwumukama,M. D. (1992) : contribution à l'étude de la qualité microbiologique de certains denrées alimentaires consommées au Burundi, Bujumbura, UB, Faculté des Sciences (département de Biologie), Mémoire, 91p.

28. Nikuze, G. (2001) : Essai d'amélioration de la qualité du vin de banane par ajout au jus des substances très riches en sucres simples Bujumbura UB, IPA, Mémoire, 78p.

29. Niziyigimana, R. (2000) : Maîtrise de l'extraction et de fermentation du jus de banane Bujumbura, UB, FACAGRO, 80p.

30. Nwobodo, H. A. (2013). Evaluation of wine produced from banana juice. World Journal of Pharmaceutical research, 2(3) 762-771.

31. Nyambirigi B. (1988) : contribution à l'étude physico-chimique des boissons alcoolisées de production local : cas de Kanyanga, Bujumbura UB. Faculté des sciences (département de Chimie), mémoire. 59p.

32. Nzigamasabo, A. \& Nimpagaritse, A.(2009).Traditional fermented foods and beverages in Burundi, Food Research International, 42 (5-6), 588-594

33. OIV, Recueil international des méthodes d'analyse des vins et des moûts, vol 1. Edition OIV Paris.523 pp.

34. Otgbayo,B.O,Akwa,I.M \& Tanimola,A.R.(2020). Physico-chemical properties of beetroot ( Beta vulgaris $l$. ) wine produced at varying fermentation days, Scientific African 8,1-9.

35. Randrianantoandro,T.L. et Andriamamisa,T.(2018).Contrôle qualité de la production de vins tropicaux malgaches en provenance de la région de Haute Matsiatra, au sud de Madagascar. Journal of applied bioscience, 122, 12248-12260.

36. Semajeje. (1986) : Essai de classification des bananiers de la collection de L'IRAZ, 107 p. 